\title{
THE UNJUST ENRICHMENT FALLACY AND PRIVATE LAW
}

Peter Jaffey, Professor of Law, Brunel University. I am grateful to participants in the Obligations VI conference for their comments.

\section{INTRODUCTION}

The most dramatic recent development in private law across much of the common law world has been the appearance of a doctrinal category of unjust enrichment. ${ }^{1}$ The new category has been formed by bringing together under a common framework various pockets of law or "doctrinal fragments" that developed separately with their own rules and concepts. On one view, this development is only a matter of convenience of exposition. It does not affect the law itself, the rules that determine what the law requires, when a claim arises and what remedy is available, and its practical significance is only that it has directed attention to certain under-explored areas of the common law. From this perspective, the intense controversy that arose over the development seems exaggerated and even pointless.

The more common view amongst its many proponents is that the recognition of a doctrinal category of unjust enrichment is more significant than this: it is justified because it represents an advance in our understanding of the law, and because in consequence it has influenced and will continue to influence the development of the law for the better, making it more rational, coherent, or just than it would otherwise have been. On this view, there is of course much more at stake in its recognition. In my view, recognition of a doctrinal category

\footnotetext{
${ }^{1}$ As reflected in English law in standard textbooks such as Graham Virgo, The Principles of the Law of Restitution, 2nd edn (Oxford: Oxford University Press, 2006) and Andrew Burrows, The Law of Restitution, 3rd edn (Oxford: Oxford University Press, 2011). The most influential academic work is usually said to have been Peter Birks, An Introduction to the Law of Restitution, rev edn (Oxford: Clarendon Press, 1989). See also Chaim Saiman, "Restitution in America: Why the US Refuses to Join the Global Restitution Party" (2008) 28 Oxford Journal of Legal Studies 99.

${ }^{2}$ This apt expression is used in Ernest Weinrib, "Correctively Unjust Enrichment", in Robert Chambers, Charles Mitchell \& James Penner, eds, The Philosophical Foundations of the Law of Unjust Enrichment (Oxford: Oxford University Press, 2009).
} 
of unjust enrichment does indeed affect the content and development of the law, but it is mistaken and hinders the proper understanding of parts of the common law, in particular the law of property and contract, and will affect its development for the worse. This becomes clear, I argue, from the consideration of two "structural" features of private law (which are important beyond the controversy over unjust enrichment), first, the nature of doctrinal categories, and, secondly, the relationship between primary and remedial rights. ${ }^{3}$

\section{DOCTRINAL CATEGORIES AND THEIR SIGNIFICANCE}

Whether the recognition of unjust enrichment as a doctrinal category is a sound development depends on how we should understand the concept of a doctrinal category and its significance in the law. I adopt the following approach. Contract law, for example, is a body of rules that give effect in law to the principle that people should keep their agreements, and the rules of contract law determine how the principle is applied - what counts as an agreement, when an agreement is enforceable, what remedies are available if the agreement is not performed, etc. The justification for a contractual claim is, in one sense, the authoritative rules applicable on the facts, but in another sense it is the underlying principle that provides the basis for the rules. In the same way, the law of negligence in tort is a body of rules based on a principle that one should bear the risk of foreseeable losses caused by one's careless or unreasonable behaviour. In these doctrinal categories, the rules laid down by the courts deal with different aspects of a general principle of liability, as they have arisen for determination across the range of circumstances in which the principle can apply. A doctrinal category is aptly described, on this model, as a "justificatory category". 4

\footnotetext{
${ }^{3}$ The discussion broadly follows that in Peter Jaffey, Private Law and Property Claims (Oxford: Hart Publishing, 2007)

${ }^{4}$ See Jaffey, ibid, ch 1 . This does not imply the rules of contract law can be derived purely from the general principle of liability and that no other principles or other considerations are relevant.
} 
This approach does not imply that the development of a doctrinal category requires the courts to identify a principle and then devise a body of rules to implement it, as a legislature might do. This is not how a doctrinal category develops in the common law. In the common law, a doctrinal category is built up gradually, through many decisions dealing with particular sets of facts, each one extending or qualifying an existing rule or adding a new rule and so contributing to the construction of the body of rules. This involves analogical reasoning, by which a court equates a new decision with a previous one or distinguishes it. ${ }^{5} \mathrm{~A}$ doctrinal category can emerge through analogical reasoning where the principle of liability is applied in making judgements of similarity or dissimilarity even though it has not been articulated. The various decisions that recognise a claim in a certain category may differ in material respects, but they are analogous to each other in the sense that they involve the application of the same principle of liability. ${ }^{6}$

This approach explains certain features of doctrinal categories in the common law. It means that a doctrinal category can develop without any explicit consideration having been given to the principle of liability; that the principle of liability may be contentious; and that there can be contested parts of the law, for which the doctrinal category is a matter of dispute. The process of analogical reasoning, and the development of the law through accidents of litigation, leave plenty of room for error and disagreement. The approach is also consistent with the fact that new doctrinal categories can appear or disappear in the law. A new doctrinal category can be created by bringing together various pockets of law or doctrinal fragments that were developed quite independently. Here the rules developed for particular types of case in particular contexts are recognised as applications in different contexts of the

\footnotetext{
${ }^{5}$ How analogical reasoning operates and whether it is really a legitimate form of reasoning are no doubt controversial, but it seems clear at least that the courts use or purport to use it and that it is the principal means by which they develop the law. My own approach is in Peter Jaffey, "Authority in the Common Law" (2011) 36 Australian Journal of Legal Philosophy 1.

${ }^{6}$ For example, according to Birks, the law of unjust enrichment is "the law of all events materially identical to the mistaken payment of a non-existent debt": Peter Birks, Unjust Enrichment, 2nd edn (Oxford: Clarendon Press, 2005), 3.
} 
same principle of liability and brought together under a common framework. Most famously, the development of the law of negligence, with the new concept of the duty of care, drew on various lines of case law covering liability in particular situations. The more recent appearance of a law of unjust enrichment seems to be a development along the same lines, based on a principle of unjust enrichment. Similarly, new doctrinal categories can arise from the division of an existing category. For example, it appears that in English law in recent years a distinct law of privacy has emerged from the old law of confidentiality, leaving a separate law of trade secrets. ${ }^{7}$

Thus doctrinal categories are not fixed: the doctrinal categories recognised for the time being constitute the current position in a continuing process by which the courts develop the law. ${ }^{8}$ At the same time, the doctrinal categories that are recognised for the time being constrain the types of claim that can arise and the way in which the law develops where it is unsettled. When it is unclear whether a claim is available on the facts, a court will consider whether the rules of one or other doctrinal category can be developed by analogy to accommodate a claim on the facts. In this way, the currently-recognised doctrinal categories limit and guide the development of the law. ${ }^{9}$ This role of doctrinal categories is in principle defensible only if a doctrinal category is indeed a justificatory category, based on a certain principle of liability.

When problematic cases cause controversy over the soundness of a doctrinal category, the controversy can be resolved in the end only by exploring the nature of the principle of liability that is supposed to provide the basis for the category. This goes beyond ordinary analogical reasoning, but it seems inevitable that the development of the common law and its

\footnotetext{
${ }^{7}$ See, e.g., Douglas v Hello [2008] 1 AC 1.

${ }^{8}$ Cf H Dagan, "Legal Realism and the Taxonomy of Private Law" in Charles Rickett \& Ross Grantham, eds, Structure and Justification in Private Law: Essays for Peter Birks (Oxford: Hart Publishing, 2008).

${ }^{9}$ Thus on the suggested approach a doctrinal category in principle corresponds to a cause of action.
} 
doctrinal categories in pursuit of sound principles of justice must involve this sort of more theoretical inquiry as well as ordinary analogical reasoning.

This general understanding of doctrinal categories draws on the dynamic and unsettled character of the common law. No doubt one should not exaggerate this aspect of the law. Generally, the common law can be satisfactorily treated simply as a body of fixed rules to be identified and applied to the facts. One could reasonably object that the law would not be performing its normal function if this were not the case. ${ }^{10}$ Insofar as the common law is understood in this way, doctrinal categories indeed serve only to assist in the exposition of the law. They have only a labelling function. Doctrinal categories on this view are inert, one might say, and at least for practical purposes there is no point in disputing the characterisation of a claim: the only sensible approach on this view is to follow whichever conventional usage has become established. This understanding of doctrinal categories is also familiar, and, as I mentioned, it accounts for the widely held view that the controversy over the development of a law of restitution or unjust enrichment was futile and misplaced. But this approach provides only a limited understanding of doctrinal categories, and it does not explain the particular problems that are in issue here, the soundness of a new doctrinal category, the role of a doctrinal category in decisions and in developing the law, and controversy about whether particular claims should be treated as falling within a certain category or not.

\section{WAS IT RIGHT TO ADOPT A DOCTRINAL CATEGORY OF UNJUST ENRICHMENT?}

The modern development of a doctrinal category of unjust enrichment is, on the face of it, consistent with the analysis above. It appears that analogous doctrinal fragments have been brought together under a common framework to establish a new doctrinal category. To some,

\footnotetext{
${ }^{10}$ This is the insight emphasised in modern legal positivism and is behind Sherwin's objections to characterising doctrinal categories as justificatory categories in Emily Sherwin, "Legal Taxonomy" 15 Legal Theory 25 (2009).
} 
the process is questionable because it involves theoretical reasoning that focuses on an abstract principle of liability rather than on ordinary analogical reasoning using concrete examples from particular decisions. ${ }^{11}$ It seems to me that this is not the right objection to make, and that, as I have said, this type of reasoning does have a role in the development of the common law. The real issue, in my view, is whether there is indeed a principle of liability - the principle of unjust enrichment - to provide a sound foundation for the new doctrinal category. It is sometimes explicitly asserted that "unjust enrichment" or "the principle of unjust enrichment" is a principle of liability, and this is sometimes taken to be self-evidently the case, ${ }^{12}$ but by contrast with the principles stated above for contract and for negligence (whatever controversy may attach to them), the principle of unjust enrichment does not appear to have been clearly formulated in a way that would allow it to be used to support and guide the development of a body of rules and a type of claim. To say that there is a principle of unjust enrichment is not in itself to state what the principle is. No formulation of the principle has attracted general support, ${ }^{13}$ and it is not in fact clear whether there is such a principle of liability at all or what it is,${ }^{14}$ though some insist that it will become clear in due course,${ }^{15}$ though there has been surprisingly little explicit discussion of what it is. ${ }^{16}$ Some proponents of the theory of unjust enrichment say that the principle of unjust enrichment is not a principle of liability in the sense above - it is not a normative or

\footnotetext{
${ }^{11}$ See for example the reference to "top-down reasoning" and the concern that analysis from an abstract framework "creates a serious risk of producing a result discordant with accepted principle" in Lumbers $v$ W Cook Builders Pty Ltd (2008) 232 CLR 635 (HC Aust), paras 75-78.

12 See, e.g., Robert Chambers, "Two Kinds of Enrichment" in Chambers et al, supra note 2, 265.

${ }^{13}$ Some possibilities are considered sceptically in Jaffey, supra note 3 , ch 8 .

14 There have been numerous unjust enrichment sceptics, including J Dietrich, Restitution: A New Perspective (Annandale: Federation Press, 1998); Steve Hedley, Restitution: Its Division and Ordering (London: Sweet \& Maxwell, 2001); IM Jackman, The Varieties of Restitution (The Federation Press, 1998); S Stoljar, The Law of Quasi-Contract, 2nd edn (Sydney: The Law Book Co, 1989); Jaffey, supra note 3, and Peter Jaffey, The Nature and Scope of Restitution (Oxford: Hart Publishing, 2000). There are others who accept a role for a principle of unjust enrichment but do not understand it as providing the basis for a doctrinal category: see e.g. SM Waddams, Dimensions of Private Law (Cambridge: Cambridge University Press, 2003), ch 1.

${ }^{15}$ e.g., Robert Stevens, "Is there a Law of Unjust Enrichment?” in S Degeling \& J Edelman, eds, Unjust Enrichment in Commercial Law (Thomson, 2008), 34.

${ }^{16}$ See the discussion in Jennifer M Nadler "What Right does Unjust Enrichment Protect?" (2008) 28 Oxford Journal of Legal Studies 245.
} 
justificatory principle, but a "descriptive" or "organising" principle, or to the same effect, it seems, a unifying concept rather than a principle. ${ }^{17}$ The idea seems to be that the principle or concept is not relevant to justifying claims in the category or determining when they are available; it is merely a useful way of arranging the material for the purposes of analysis. But in what way is it useful? According to Burrows, ${ }^{18}$ this way of arranging the material is apt for analysis because it brings together cases that are relevantly similar and separates out cases that are relevantly dissimilar. If this is the case, however, it seems that the principle must be a principle of liability, since the similarity and dissimilarity of cases must presumably be concerned with whether they share the features that are relevant to liability. More generally, if the category is not a justificatory category, there is no justification for the way it is employed in legal reasoning. Treating all cases in a category as analogous to each other and uniting them under a common body of rules makes sense only if the category is a justificatory category based on a principle of liability. If it is contentious whether a claim is an unjust enrichment claim or in what circumstances it should arise, the solution lies in investigating the principle of liability. ${ }^{19}$

The absence of any consensus over the nature of the principle of unjust enrichment gives some support to the sceptical position. Further support comes from the fact that it is easy to see how the theory of unjust enrichment could have arisen from a misunderstanding. It seems very plausible that what cases of unjust enrichment really have in common is not a

\footnotetext{
${ }^{17}$ There is a "concept" of unjust enrichment, which is not a principle, according to the High Court of Australia in Bofinger v Kingsway Group Ltd (2009) 239 CLR 269, para 85. The expression "unifying legal concept" was used by Deane J in the important case of Pavey \& Matthews Pty Ltd v Paul (1987) 162 CLR 221.

${ }^{18}$ Burrows, supra note $1,4$.

${ }^{19}$ In recent years, the concern has been with whether the established "unjust factors" approach is preferable to the "absence of basis" approach: see, e.g., Burrows, supra note 1, ch 5. To my way of thinking, this is a distraction from the fundamental issue of identifying a principle of liability. It might be argued that the category of unjust enrichment is like the doctrinal category of tort, and tort, it might reasonably be said, is not a doctrinal category based on a single principle of liability, but a collection of different types of claim based on different principles of liability. Possibly this is the implication of the "unjust factors" approach. See, for example, the discussion in SA Smith, "Unjust Enrichment: Nearer to Tort than Contract" in Chambers et al, supra note 1. This may well be the right way to understand tort law, but if so tort law as a whole is not a doctrinal category in the particular sense I have suggested above. The doctrinal categories would be the particular torts, such as negligence, defamation, etc.
} 
principle of liability but a type of remedy. This is, of course, consistent with the fact that what is now commonly described as the law of unjust enrichment was until recently described as the law of restitution, and developed to address the problem of explaining various types of claim that had a certain remedy in common, namely restitution, understood as the remedy of undoing a transfer, or requiring payment for a benefit. ${ }^{20}$ If it is the type of remedy that characterises the law of unjust enrichment, and not a justifying principle, it is a mistake to recognise it as a doctrinal category, just as it would be a mistake, say, to unify contract and negligence on the ground that they generally involve the same remedy of compensation. This objection gains support from the way in which the principle of unjust enrichment is often expressed, as the principle that unjust enrichments should be reversed or undone. ${ }^{21}$ This is not a principle of liability, since it does not bear on whether an enrichment is unjust or not; it holds that if an enrichment is unjust there should be a remedy to undo it. Furthermore, the standard unjust enrichment analysis of a claim is by reference to the three-stage framework, which requires that (1) there is a benefit to D, (2) the benefit is at C's expense, and (3) there is an "unjust factor". This formulation is quite consistent with the possibility that the category is really a remedial category, just as one could bring together claims for compensation for loss and then classify them according to "unjust factors" such as "failure to act as agreed" or "failure to exercise reasonable care". This I will refer to as the "remedy-as-justification" fallacy, the fallacy of treating a remedial category as if it were a justificatory category. ${ }^{22}$

No doubt it is possible in the common law for the courts to develop a new, sound doctrinal category by bringing together various parts of the law without being able to discern or articulate fully the principle of liability that justifies the development. But if the new category is indeed a sound category based on a genuine principle of liability, one would expect to see some assimilation of the different doctrinal fragments so that in due course their

\footnotetext{
${ }^{20}$ It might be better to say that there is a group of benefit-based remedies.

${ }^{21}$ e.g., Burrows, supra note $1,3$.

${ }^{22}$ See Jaffey, supra note 3, 17.
} 
separate origins become obscured or even entirely concealed, and it seems to me doubtful whether this is happening to any degree in the case of unjust enrichment. Although it has become customary to recite a standard unjust enrichment framework, it seems to me that on the whole the strands of authority have remained separate. Furthermore, one would expect the development to be productive in resolving or at least casting light on some existing problems through the new insights or comparisons that it generates. But, again, it seems to me doubtful whether any problems have been solved through the application of a principle of unjust enrichment or the development of a doctrinal category of unjust enrichment. ${ }^{23}$

If there is in fact no principle of unjust enrichment, the recognition of the doctrinal category is a source of incoherence and obscurity and confusion in the law. It brings together for common treatment cases that should be treated separately and it separates out for different treatment cases that should be treated in the same way. It obscures the real issues and obstructs the development of the law according to sound principles.

The reason why the category of unjust enrichment has been so beguiling is not, it seems to me, the appeal of the principle of unjust enrichment or its success in illuminating and solving problems in the law. It is because it seems impossible to explain the longestablished claims for restitutionary remedies that arise in connection with the nonperformance of a contract or with transfers of property (the majority of claims for restitutionary remedies) as claims arising in contract law or property law, according to the conventional understanding of these areas. ${ }^{24}$ The issue here is the relationship between primary and remedial relations.

\footnotetext{
${ }^{23}$ I am not suggesting that the literature does not contain valuable and useful contributions to our understanding, but that these do not arise from the elucidation or application of a principle of unjust enrichment or from the recognition of the doctrinal category or the reorganisation of material involved in this.

${ }^{24}$ Not all claims that are said to be unjust enrichment claims can be explained in terms of property or contract, and this is sometimes said to be a point in the favour of the theory of unjust enrichment: see Lionel Smith, "Unjust Enrichment, Property, and the Structure of Trusts" (2000) 116 Law Quarterly Review 412, 419. In the end everything turns on what principle of liability is offered.
} 


\section{REMEDIES AND THE VINDICATION OF PRIMARY RIGHTS}

In a typical case in private law, according to the usual understanding, C's claim arises from the breach by $\mathrm{D}$ of a duty owed to $\mathrm{C}$. What should the legal consequences be? It is helpful to distinguish between two sorts of legal consequences. First, there is a sanction or penalty. I take a sanction or penalty to be a measure imposed as a matter of public interest to deter or punish the breach of duty, and I will leave this type of measure aside. ${ }^{25}$ Secondly, there is a remedy, in the strict sense, which protects the interest of the particular claimant and corrects the injustice done to him. ${ }^{26}$ The appropriate remedy to achieve this follows from the content of duty breached. The rationale for the remedy is to secure to $C$ the benefit of the duty he was owed. This is achieved by ordering D to perform the original duty, or to provide some equivalent performance, or to pay $\mathrm{C}$ compensation measured by what the performance of the duty was worth to C. Sometimes, after the breach, it is impossible to secure the performance of the original duty, as in many cases of injury or damage, and even if it is possible one might say that sometimes it is unfairly burdensome to $\mathrm{D}$ to require it, and $\mathrm{C}$ should be limited to compensation. But, subject to this point, one can say that the remedy should protect C's right by securing to him the benefit of the right, or in other words the benefit of the performance of the duty owed to him. This I will refer to as vindicating the right. ${ }^{27}$ It is convenient to distinguish between primary and remedial relations in the following way. The primary relation is the duty D has, and C's correlative right, in the first place, which determines what constitutes a breach of duty and so when a claim arises, and the remedial relation is C's right

\footnotetext{
${ }^{25}$ Of course, some approaches - in particular, the economic analysis of law - do understand the law in terms of measures to deter or more broadly to create incentives and disincentives.

${ }^{26}$ I take it that this is the traditional view of the role of civil proceedings, reflected in the bilateral character of civil proceedings and the contrast between civil and criminal proceedings, and nowadays associated with the corrective justice approach to private law.

${ }^{27}$ I use the expression in this particular sense: recent discussion of the idea of vindication have suggested various approaches. See for example David Pearce \& Roger Halson, "Damages for Breach of Contract: Compensation, Restitution and Vindication” (2008) 28 Oxford Journal of Legal Studies 73. On my approach, this is a matter of consistency between primary and remedial relations, given that a remedy is justified. I discussed this previously in terms of remedial "monism" and "dualism": see Jaffey, supra note 3, ch 2. I leave aside the controversy over why there should be a right to a remedy at all.
} 
to a remedy and D's correlative duty or liability to provide it, which arises from the breach of duty and serves to vindicate the primary relation.

According to the pattern assumed above, the primary relation is a right-duty relation, requiring $\mathrm{D}$ to act or not to act in a certain way. But this need not be the case. The injustice that a primary relation specifies and a claim in private law corrects should not necessarily be understood as a breach of duty and its consequences. Sometimes the primary relation should be understood simply as an allocation of prospective benefits or harms, so that $\mathrm{D}$ bears responsibility for a specified risk or contingency vis-à-vis $\mathrm{C}$, and if the contingency materialises a claim arises for $\mathrm{C}$ against $\mathrm{D}$. The injustice consists of the state of affairs following the materialisation of the contingency, and the appropriate remedy to vindicate the primary right is to secure the proper allocation of the benefit or harm in question. The injustice does not involve a breach of duty and the remedy does not correct a breach of duty. For example, some commentators take the view that a claim in negligence arises from a loss caused by the defendant's conduct having fallen below a specified standard of conduct, without any requirement that this constituted a breach of duty by D. The law simply imposes responsibility for this loss on $\mathrm{D}$ rather than $\mathrm{C}$, without necessarily imposing a duty on $\mathrm{D}$ not to act in this way or not to cause loss in this way. On this view, although it is conventional to say that the claim arises from a breach of the duty of care, the supposed duty is just a way of defining the contingency for which $\mathrm{D}$ is responsible. I give this example by way of illustration, and it is not necessary for present purposes to consider whether this is the right way of understanding negligence.

Some commentators would object that there simply cannot be primary relations of this sort in private law, or at least that there ought not to be as a matter of justice, possibly on the basis that one person cannot incur a liability to another except by wronging him, and possibly on the basis that liability without wrongdoing introduces inappropriate considerations of 
policy into private law. I do not think these objections are right, though they raise important questions which I will not attempt to address here. For present purposes, I will simply point to what do appear to be examples of primary relations of this sort, and identify what seem to me to be plausible private law principles of liability that give rise primary relations of this sort.

If the appropriate remedy follows directly from the primary right, to vindicate it, the primary relation and the remedial relation are based on and together give effect to the same principle of liability and should be treated together as parts of the same doctrinal category. The category encompasses the rules determining the primary relation and the rules governing its vindication in various circumstances by the remedial relation. This is the usual understanding in contract law, which is understood to encompass the rules governing the primary relation - usually understood as the duty to perform the contract and the correlative right to receive performance - and also the rules governing the remedial relation - the right to specific performance or compensation that arises from a breach of contract. Similarly the category of negligence encompasses the duty of care and the right to compensation that arises from a breach of the duty.

\section{RESTITUTION IN CONTRACT LAW}

On the standard analysis of contract law, the primary relation consists of a duty to perform and a right to receive performance, and the appropriate remedy is specific performance or expectation damages, which vindicate the primary relation. One might say, on this view, that contract law generates only an "expectation interest" or "performance interest" ${ }^{28}$ Consider reliance damages, by contrast. Reliance damages are not, on the face of it, apt to vindicate the primary right, because they do not serve to correct the wrong by giving $\mathrm{C}$ the benefit of the

\footnotetext{
${ }^{28}$ Daniel Friedmann, “The Performance Interest in Contract Damages” (1995) 111 Law Quarterly Review 628.
} 
duty owed to him. Thus where reliance damages are awarded, they are taken to be a proxy for the expectation measure, and for this reason recovery is not allowed to exceed the expectation measure if $\mathrm{D}$ can show what this is. ${ }^{29}$ There is no right to protection for reliance loss as such, or in other words, no distinct "reliance interest" under the contract. ${ }^{30}$

Sometimes $\mathrm{C}$ is allowed to recover a payment made under the contract, or is given a quantum meruit for goods or services supplied under the contract. ${ }^{31}$ These are commonly described as restitutionary remedies, and again it appears that, as for reliance damages, a claim for a restitutionary remedy cannot be understood to arise from the contract, because the restitutionary remedy does not vindicate the primary right to receive performance: it does not correct the wrong of non-performance by fulfilling or giving effect to the primary right to performance. Under the standard analysis, there is no contractual "restitution interest", any more than there is a contractual reliance interest. Furthermore, a restitutionary remedy cannot be understood as a proxy for the expectation measure. The measure of recovery is allowed to exceed the expectation measure, and moreover there can be a claim where D clearly has not committed a breach of his duty of performance, for example on frustration or where it was $\mathrm{C}$ who breached the contract. Thus if a claim for a restitutionary remedy should sometimes be available in the contractual context, as for example where $\mathrm{C}$ has paid in advance and $\mathrm{D}$ has done nothing in return, it seems that it must be a claim arising by virtue of some other principle of liability, in some other doctrinal category. This is taken to be unjust enrichment, and the restitutionary remedy is understood as a remedy that serves to remove a benefit from $\mathrm{D}$ or require $\mathrm{D}$ to pay for a benefit. ${ }^{32}$ This seems to be the main reason why the claim is understood to be an unjust enrichment claim, though obviously it falls short of providing a

\footnotetext{
${ }^{29}$ C \& P Haulage v Middleton [1983] 1 WLR 1461

${ }^{30}$ David McLauchlan "Reliance Damages for Breach of Contract" [2007] New Zealand LR 417

${ }^{31}$ See generally Burrows, supra note 1, ch 15; Virgo, supra note 1, ch 12.

32 This appears to be the standard approach in virtually all the contract and restitution textbooks.
} 
positive unjust enrichment account, which would involve explaining what the principle of liability is. ${ }^{33}$

The usual unjust enrichment analysis of the claim for a restitutionary remedy in the contractual context does not explicitly state a principle of liability. It specifies an unjust factor, which is said to be "failure of basis" or "failure of condition". ${ }^{34}$ It is said that C performs the contract on the basis that $\mathrm{D}$ will provide reciprocal performance, and that if $\mathrm{D}$ does not do so $\mathrm{C}$ can recover his performance because the basis on which it was provided has failed. The restitutionary remedy is understood as the return of the contractual performance. ${ }^{35}$ But in fact the basis on which the parties perform is the agreement - it is the function of the agreement to determine the basis on which the parties perform. According to the standard analysis, the parties perform on the basis that the other party has a reciprocal duty of performance, and the appropriate remedy, if the reciprocal performance is not provided, is specific performance or expectation damages to vindicate the right to performance and the duty to provide it. No doubt $\mathrm{C}$ and $\mathrm{D}$ could agree that performance is to be returned if there is no reciprocal performance, and then a restitutionary remedy would vindicate the primary right and the claim would be contractual. But otherwise it is inconsistent to say that the parties make a contract, understood in accordance with the standard analysis, and also that they contract on the basis that performance is returnable if the agreed reciprocal performance is not provided.

\footnotetext{
${ }^{33}$ One might argue that the role of unjust enrichment is to extend the protection given to contractual rights by providing additional remedies on contractual termination that contract law does not. On this view, one might say that unjust enrichment is a remedial doctrinal category, concerning with determining when a particular remedy is appropriate to provide extra protection for a primary right arising in another doctrinal category, such as contract. I understand this to be Friedmann's approach: see e.g. Daniel Friedmann, "The Creation of Entitlements through the Law of Restitution", in Rickett \& Grantham, supra note 8, 185. But if we accept the approach adopted above, the appropriate remedies to protect a primary right are a matter of what is necessary to vindicate it, and this is an aspect of the law of contract.

${ }^{34}$ e.g., Burrows, supra note $1,319$.

${ }^{35}$ This way of putting it characterises contractual performance as a transfer, which is apt in my view only for transfers of money or property: see infra at note 61 .
} 
In reality, the argument for an unjust enrichment claim arising by virtue of failure of basis or failure of condition does not provide a distinct non-contractual basis for a claim. It does not identify a non-contractual principle of liability. It makes sense only as a contractual claim, on the assumption that the parties contract on a different basis from what is assumed by the standard analysis. If, as the standard analysis holds, the contract consists of an exchange of promises to perform, generating duties to perform, there is no room for restitutionary remedies at all; but if the parties agree to perform on the basis that their performance is returnable in the absence of reciprocal performance, the restitutionary remedies are appropriate but specific performance and expectation damages would appear not to be. These are two possible bases for performance, corresponding to two different ways of understanding what was agreed and its legal effect, and they are mutually exclusive and cannot both represent the basis on which the parties perform in a particular case.

On what basis do the parties actually perform? That is to say, how should we understand the agreement and its legal effect? It seems reasonable to ask whether there is a way of understanding an agreement - a possible basis for contracting - that explains the availability of the various remedies that can arise out of a contract, including expectation damages, specific performance, and also the restitutionary remedies, as being in each case the appropriate remedy to vindicate the agreement in the particular circumstances in which it is available. This brings into consideration another longstanding puzzle concerning contract remedies. If a contracting party has a duty to perform, as the standard analysis holds, why is it that a contracting party who has failed to perform is not in the usual case ordered to do so, even when performance has not become any more burdensome as a result of the breach; and why is he not in any other way treated as having acted wrongfully, for example by being required to disgorge the profits of breach? Under the standard analysis, this seems to be a clear failure of vindication. 
It seems to me that there a way of understanding an agreement that can explain the remedial regime in contract, as I have argued elsewhere. ${ }^{36}$ On this approach, a contracting party is understood to proceed on the basis that the contract protects his contractual reliance interest, the interest in being compensated or paid for what he has done so far under the contract. The agreement between contracting parties involves each party accepting responsibility for the other party's reliance on the assumption that the contract will proceed as specified, rather than undertaking to perform. On this understanding, a contracting party should be entitled to a restitutionary remedy, to return money he has paid or provide payment for what he has done under the contract. In my view, insofar as restitutionary remedies are rightly awarded as a remedy in the event of non-performance of a contract, it is because the agreement is along these lines. One might object that on this account expectation damages cannot be justified, since expectation damages are normally understood to be justified only because they serve to correct a breach of the duty to perform the contract and on this account there is normally no duty to perform the contract. But, as has often been pointed out, the suggested account can explain the availability of expectation damages as a proxy for reliance loss, including opportunity cost, in the generality of cases. It can also explain why it is that specific performance is not generally available, since in the ordinary case there is no duty to perform.

Whether or not this suggested contractual approach is accepted, it at least demonstrates the possibility of a contractual analysis of restitutionary remedies in contract. On a contractual analysis, the injustice that a claim for a restitutionary remedy corrects is a contractual injustice, an injustice relative to the primary relation generated by the agreement. On the suggested approach, the primary relation is not in general a right-duty relation: it follows the alternative pattern mentioned above according to which it amounts to an

\footnotetext{
${ }^{36}$ Jaffey, supra note 12, ch 2 and Peter Jaffey, "Restitutionary Remedies in the Contractual Context" (2013) 76 Modern Law Review (forthcoming).
} 
allocation of prospective benefits or losses. Maybe a different contractual account is available which shows in a different way how a restitutionary remedy can vindicate an agreement. By contrast, it seems to me that the unjust enrichment approach has not managed to find any distinct non-contractual account of restitutionary remedies arising from the non-performance of a contract. This tends to support the idea that the unjust enrichment approach involves a version of the "remedy-as-justification" fallacy. Starting from the position that a claim for a restitutionary remedy is apt in certain circumstances in the contractual context, and on the assumption that it cannot have a contractual basis, it is inferred that there must be some other justification for a claim for such a remedy, which is taken to be the principle of unjust enrichment, though the principle is not actually spelt out, or when it is spelt out it appears to be a disguised form of the contractual principle.

\section{RESTITUTION IN PROPERTY LAW}

\section{The same problem in property law}

The same fallacy has affected the law of private property. Some would say that only a tangible thing can be an "object of property", ${ }^{37}$ but I will assume (I will come back to this point) that the object of property, which I will refer to as the property or the asset, can also be an intangible thing, including a transferrable contractual right such as a right of payment against a bank. ${ }^{38}$ Say $\mathrm{C}$ is the owner of property, which is invalidly transferred to $\mathrm{D}$, that is to say it comes into the control or possession of D without a valid exercise of C's power of transfer as owner. ${ }^{39}$ The natural way to understand the legal position is that $\mathrm{C}$ has a claim to recover the property because his right of ownership of the property is unaffected by the invalid transfer. In the sense suggested above, the claim to recover the property vindicates the primary right of ownership, i.e. it secures to $\mathrm{C}$ the benefit of his primary right. The claim here

\footnotetext{
37 e.g., Ben Macfarlane, The Structure of Property Law (Oxford: Hart Publishing, 2008), 132.

${ }^{38}$ This is not meant as an exhaustive list of possible objects of property.

${ }^{39} \mathrm{I}$ am avoiding various other expressions used in this context, such as void, voidable, ineffective etc.
} 
is surely just a matter of property law, as I think would be generally accepted, even if it may commonly take the conventional form of trespass or conversion. However, if it is to be understood in accordance with the pattern suggested earlier, the implication is that there is a doctrinal category of private property, with its own principle of liability, covering at least this type of claim, and some will find this less palatable. I will come back to this point below.

Say instead the property invalidly transferred is lost in a mixture or is incorporated into other property of D's. The standard analysis here is that the original right of ownership is lost, because the property - the object of the right - is lost, and instead, because of the invalidity of the transfer, $\mathrm{C}$ acquires a personal claim for restitution of the value of the transfer. It seems that this claim cannot be a matter of property law, since the right of ownership has been lost. In the case where the property is money, in some circumstances it is said that, although the transfer was invalid, title passes to D in order to protect the interest of third parties in being able to rely on the character of the property as money, and so again $\mathrm{C}$ has lost his right of ownership and can have no claim as a matter of property law. Again, since the transfer was invalid, there should be a personal claim for restitution of the transfer. In these cases, it seems that, because the claim cannot be a matter of property law, it must be a claim in a distinct doctrinal category, which is understood to be unjust enrichment.

This brief account is not intended to do justice to the detail of the relevant law, merely to show why it is thought that these claims must be unjust enrichment claims. But is there really a distinct basis for an unjust enrichment claim outside property law, and if so what is the nature of the injustice and the principle of liability? This is not at all clear. As discussed above, the standard approach to unjust enrichment does not explicitly identify a principle of liability. It merely points to an unjust factor that triggers an unjust enrichment claim in particular circumstances. In this type of situation, the unjust factor is said to be a vitiating factor such as mistake, or lack of authority for the transfer, where the transfer is made by 
someone else. ${ }^{40}$ But what is it that is vitiated if it is not the exercise of the owner's power to transfer his property, and what authority is relevant other than the authority to exercise this power? And what is it that is not validly transferred if it is not the right to the property? Where it is said that there has been a valid transfer of ownership of the property, but the transfer is nevertheless vitiated in some way so as to give rise to a claim in unjust enrichment, how can there be an injustice to $\mathrm{C}$ arising from the transfer of his property if his property has been validly transferred? It is difficult to see what interest of C's is at stake other than his interest as a property owner, or what other sort of injustice is at stake other than the injustice of a transfer of his property without a valid exercise of his owner's power of transfer. ${ }^{41}$

\section{How to understand the property-based claim for restitution}

In my view, just as for the analysis of contract above, the unjust enrichment approach does not, in the end, identify any distinct basis for a claim to recover the transfer. The claims described above are in principle all a matter of property law, ${ }^{42}$ just as the claim for a restitutionary remedy in the contractual context, where it is available, is a matter of contract law. C has a primary right of ownership of the property, and his claim - the remedial right arises to vindicate the primary right of ownership in the particular circumstances that have

\footnotetext{
${ }^{40}$ It is sometimes said that the unjust factor is "ignorance": see, e.g., William Swadling, "Ignorance and Unjust Enrichment: the Problem of Title" (2008) 28 Oxford Journal of Legal Studies 627. In my view, the relevant condition is better understood as lack of authority or power: see Jaffey, supra note 12, 160-2. So far as I can see this does not affect the present issue.

${ }^{41}$ See Nadler, supra note 14. See also Andrew Botterel, "Property, Corrective Justice, and the Nature of the Cause of Action in Unjust Enrichment" (2007) 20 Canadian Journal of Law and Jurisprudence 275. It might be argued that the law of unjust enrichment is a remedial doctrinal category concerned (inter alia) with providing additional remedies to protect the right of ownership where a remedy is justified but property law cannot provide it: see e.g. Friedmann, supra note 25 . But, echoing what was said above about contract, the appropriate remedy for a claim arising from the primary right of ownership depends on what is necessary to give effect to the principle of liability by vindicating the primary right, and this is a matter of property law. If there is a distinct unjust enrichment claim, it must be based on a different principle of liability, though one that in some sense draws on the right of ownership.

42 There are other analyses based on property rather than unjust enrichment, or that distinguish transfers of property from conferring benefits by the provision of services: e.g. S Stoljar, The Law of Quasi-Contract, 2nd edn (Sydney: The Law Book Company, 1989); Charlie Webb, "Property, Unjust Enrichment, and Defective Transfers", in Chambers et al, supra note 2; Peter Watts "Restitution - A Property Principle and a Services Principle" [1995] RLR 49.
} 
arisen, viz, the invalidity of the transfer. The problem is, if the primary right was a right of ownership of the original property transferred, how it can be vindicated otherwise than by the recovery of the original property. The answer is that one can treat the transfer of property, though it was in the form of a tangible thing or other specific asset, as a transfer of wealth, which contributes wealth to D's estate. The property transferred is treated as wealth in just the way that a bankrupt's estate or a deceased's estate is treated as wealth, the tangible things and specific assets that make it up being treated simply as embodiments of exchangeable or realisable value. The specific asset transferred enters D's estate, and C cannot assert ownership of it, but he has a claim to the wealth transferred, and this vindicates the primary right of ownership in the sense explained above, that is to say it secures to $C$, in the way that is appropriate in the circumstances, the benefit of his right under the primary relation. Thus the claim is a matter of property law, i.e. a property-based claim.

A claim to recover wealth or value is conventionally understood as a personal claim, meaning that the remedy is equivalent to a debt for the value of the transfer. This is how the common law claim for restitution is understood, for example the claim to recover a mistaken payment. The contrast is with what is conventionally described as a proprietary claim, usually understood as a claim of ownership of a specific asset, which is capable of being extracted from D's estate and returned to C. For many commentators, it is because the claim is personal in this sense that it must be an unjust enrichment claim rather than a matter of property law. ${ }^{43}$ But even if it is right that the claim to recover a mistaken payment should be a personal claim because it is a claim to recover wealth rather than a specific asset, it is nevertheless in my view a property-based claim in the sense that it arises to vindicate a primary right of ownership. In any case, the remedy is not in principle equivalent to debt or damages. It is in principle a claim to a defined part of D's estate, though not necessarily a specific asset. This

\footnotetext{
43 e.g., Weinrib, supra note 1.
} 
is that part of D's estate, considered as a body of wealth, that would not have been there in the absence of the transfer, that is to say it is the "surviving value" of the transfer. A claim to this part of the estate is capable of binding indirect recipients, including creditors; indeed in principle it ought to, because one can identify a transfer of surviving value, defined in this way, to an indirect recipient, and the indirect recipient should in principle be liable to surrender the surviving value just as a direct recipient is. ${ }^{44}$ In addition, it is worth noting that the surviving value will often be the value of the original asset and so a claim in respect of surviving value can be satisfied by returning the asset. In fact, it is normally only when the asset is treated by D as wealth, rather than as a specific asset valuable as such, that the surviving value is liable to depart from the value of the specific asset in D's estate. It is only at this point that the claim has to be treated as a claim to the surviving value rather than to the specific asset.

Although the common law claim for restitution is not recognised as proprietary, it is increasingly being understood in a way that is consistent with this analysis. Whereas the traditional approach was to treat the claim as equivalent to a claim to recover a debt in the measure of the transfer, subject to reduction for change of position by way of a defence, it is increasingly common to think of change of position as going to reduce the measure of recovery, so that the claim is to recover D's continuing or surviving enrichment. ${ }^{45}$

\footnotetext{
${ }^{44}$ It might be said that a claim will arise against an indirect recipient only if the indirect recipient has received property belonging to the claimant, and not merely because there has been a transfer of value from the claimant to the indirect recipient according to a causation test. But of course this includes the case where the indirect recipient receives traceable proceeds of the original asset and as suggested below it is not clear that tracing can be justified in principle otherwise than as a way of determining surviving value.

${ }^{45}$ See, e.g., Chambers, supra note 10,248 . There is another problem relating to the common law. One might say that if a transfer is invalid it is no transfer at all, or at least there is merely a transfer of possession or control that the law does not recognise as having any legal effect as a transfer. But in fact an invalid transfer from C to D can have legal effect in giving the recipient of the transfer $\mathrm{D}$ the power to dispose of the specific asset transferred in favour of third parties. At the same time $\mathrm{C}$ should retain the right to the value of the transfer as against third parties. Thus one might want to say that title has passed to $\mathrm{D}$ in one sense, relating to control of the asset, but retained by $\mathrm{C}$ in another sense, relating to the value of the transfer, or in other words that the adequate treatment of an invalid transfer calls for two concepts of title. Equity's more sophisticated treatment of invalid transfers results from the fact that it did develop two concepts of title - the former is how legal title should be understood, in my view, and the latter is how beneficial or equitable title should be understood.
} 
The equivalent claim in equity is the equitable proprietary claim, which traditionally takes the form of a claim to recover a transfer of trust property that is invalid because it was made by a trustee or fiduciary acting beyond his powers. According to the conventional analysis, the fact that the claim is proprietary means not that the beneficiary $\mathrm{C}$ has a right to surviving value, but that he retains beneficial ownership of the specific asset transferred. However, there is a longstanding problem affecting the equitable proprietary claim, namely how to explain the law of tracing. Although the equitable proprietary claim is understood to be a claim of beneficial ownership of the specific asset transferred, if this asset is exchanged for some other asset, C's proprietary claim is, as it were, transmitted to the new asset, the exchange property. The rationale for this is controversial. The remedy should vindicate the primary right, and if the primary right was a right of beneficial ownership of the original asset, how can it be vindicated by transmitting it to a different asset? The principle of unjust enrichment is sometimes taken to explain this, that is to say the claim to the exchange property is said to arise to prevent D's unjust enrichment. ${ }^{46}$ But, again, this seems to me unsatisfactory because it does not identify a distinct principle of liability, or explain how the principle relates to the primary right of ownership. ${ }^{47}$ It seems to me that the most plausible if not the only plausible rationale for the tracing rules is that fundamentally the claim is to surviving value, which the tracing rules serve to identify. The tracing rules take the form of identifying specific assets, and the claim is conceived as jumping from asset to asset because of the mistaken assumption that the proprietary claim must take the form of a claim in respect of a specific asset. ${ }^{48}$

\footnotetext{
${ }^{46}$ Though this is not at all the uniform view amongst supporters of the theory of unjust enrichment: see e.g. Lionel Smith, "Philosophical Foundations of Proprietary Remedies" in Chambers et al, supra note 2. For another recent attempt to provide a theoretical account of the law of tracing, see J Penner, "Value, Property, and Unjust Enrichment: Trusts of Traceable Proceeds" in Chambers et al, ibid.

${ }^{47}$ In Foskett v KcKeown [2000] UKHL 29, the House of Lords took the view that the tracing rules are a matter of property law.

${ }^{48}$ As explained more fully in Jaffey, supra note 3, ch 6. See also EL Sherwin "Constructive Trusts in Bankruptcy" 1989 University of Illinois Law Rev 297; S Evans "Rethinking Tracing and the Law of Restitution2 (1999) 115 Law Quarterly Review 469.
} 
The suggested approach is that the claim for restitution of an invalid transfer of property (which includes the common law claim for restitution and the equitable proprietary tracing claim) is always a remedial right arising to vindicate the primary right of ownership, and so is always a matter of property law, though it is a claim for surviving value and not necessarily a claim to recover the original asset transferred. This approach provides a possible account of the law, though it would call for some changes to the current rules, and it is an attractive account in my view because it optimises the protection for the owner whilst also respecting the rights of the recipient and third parties, who are not prejudiced if the claim is limited to surviving value. ${ }^{49}$ The alternative, which I have argued is mistaken, is to insist that property law is limited to providing a claim to the original asset, and that any further claim must be based on a distinct principle of unjust enrichment. This is equivalent to the position referred to above with respect to contract, where the principle of unjust enrichment is invoked to explain claims that arise out of the non-performance of a contract but cannot be explained as contractual claims under the standard analysis of contract. Again, in my view, the unjust enrichment approach involves the remedy-as-justification fallacy. From the starting point that a claim for restitution is justified, and on the assumption that it is inexplicable as a claim based on the original right of ownership, it is inferred that there must be a principle of unjust enrichment to account for it. This has the effect of obscuring the real issue, which is what remedy is appropriate in the circumstances to vindicate the original right of ownership.

Most accounts of property and unjust enrichment argue in favour of (or simply assume) what I have denied above, that there is a genuine distinction, based in principle, between the claim that arises as a matter of property law by virtue of the invalidity of a transfer, and the unjust enrichment claim that arises where the transfer was valid as a matter

\footnotetext{
${ }^{49}$ For the benefit of $\mathrm{C}$, it is best to treat the invalid transfer as a transfer of abstract value because $\mathrm{C}$ is then less likely to be adversely affected by transactions relating to the specific property transferred, and treating the claim as a claim to causally-determined surviving value also protects D and third parties (including D's creditors) because it means that the value of D's estate available to D and third parties cannot be less than it would have been in the absence of the invalid transfer (change of position is incorporated into the tracing rules).
} 
of property law but was nevertheless in some other way defective. Weinrib has the following account of the distinction. ${ }^{50} \mathrm{He}$ takes the position rejected above, that property law ceases to be relevant if the claim is not to recover the specific asset transferred, because the primary right of ownership of the asset has been extinguished. Since the claim is not based on ownership, it must lie in the relationship between the parties, arising from the particular interaction between them. More particularly, according to Weinrib, the claim arises from two “obligation-creating conditions", the fact that C's intention to make the payment was vitiated, and the fact that D accepted the payment when he knew this was the case or in circumstances in which he should be taken to have accepted the risk that it was the case. These circumstances justify a personal rather than a proprietary claim and a corresponding liability as between $\mathrm{C}$ and $\mathrm{D}$.

However, the claim for restitution surely arises because and insofar as D is in surplus as a result of his receipt of the invalid transfer - insofar as he is enriched by it - and this does not in principle depend on whether $\mathrm{D}$ knew or is deemed to have known that the transfer was invalid. ${ }^{51}$ This is how the claim is understood in the case law and literature, whether it is understood as a property-based claim or as an unjust enrichment claim. There is another type of claim that should in principle depend on actual or deemed knowledge of the invalidity of the transfer, which should be distinguished from the restitutionary claim. If D has received an invalid transfer, and he knows or ought to know of the invalidity, he should incur a duty not to consume or dispose of what he has received, for breach of which duty he should be liable to compensate $\mathrm{C}$ for any resulting loss. This claim of C's should in principle be a personal

\footnotetext{
${ }^{50}$ Weinrib, supra note 1. For another account of the distinction, see Nadler, supra note 14.

${ }^{51}$ A point made by Zoe Sinel, "Through Thick and Thin: The Place of Corrective Justice in Unjust Enrichment" (2011) 31 Oxford Journal of Legal Studies 551 at 557. According to Weinrib, supra note 1, the claim cannot be understood as a claim in respect of the wealth as a thing, as if it were a matter of property, because this would not explain the fact that the law has different tests of validity for transfers depending on whether the claim is a matter of property or unjust enrichment, nor would it explain the requirement for acceptance of the transfer by the recipient. But the problem is surely to explain why there is a difference insofar as this is the case; and on my understanding there is not generally any requirement of acceptance.
} 
claim against $\mathrm{D}$. It is not a claim to recover what was transferred. It is really, in my view, a matter of negligence. It is a claim for compensation for loss arising from D's having fallen short of the prescribed standard for monitoring transfers for invalidity and preserving what he receives through an invalid transfer. This is a distinct claim, based on a distinct principle of liability, though it is concerned with protecting property. More generally, in my view, although it is only partly manifested in the case law, in principle the protection of property owners in respect of invalid transfers involves these two types of claim, the claim for restitution to recover the surviving value of the transfer, and the claim for compensation for loss caused by a breach of the duty of a recipient to preserve or not to consume or dispose of property received through an invalid transfer. ${ }^{52}$

\section{The "duty of exclusion" conception of private property}

Finally, I will touch briefly on two general aspects of private property that might be thought problematic for the approach I have suggested above. The first of these relates to the common assumption that a right of ownership should be understood as a right correlated with a duty not to enter or encroach on or misappropriate or dispose of property, a "duty of exclusion". ${ }^{53}$ It presumably follows from this assumption that a claim to vindicate a right of ownership is a claim arising from a breach of such a duty. However, as I have just pointed out, a claim for restitution of an invalid transfer is normally understood to arise from the receipt of the invalid transfer and the subsistence in D's estate of surviving value, and this surely does not in itself constitute a breach of duty by $\mathrm{D}$, since it was beyond his control. The claim for restitution of the transfer has to be distinguished from the claim that arises from the breach of a duty not to

\footnotetext{
${ }^{52}$ At common law, tort law in the form of trespass or conversion combines these two distinct roles, sometimes leading to injustice. See, e.g., T Weir, Introduction to Tort Law, 2nd edn (Oxford: Clarendon Press, 2006), 1667. Equity comes closer to distinguishing between the two claims by way of the equitable proprietary claim and knowing receipt, as discussed in Jaffey, above n3, ch 7.

53 e.g., Macfarlane, supra note 28, 194; JW Harris, Property and Justice (Oxford: Oxford University Press, 1996), 24; J Penner, The Idea of Property in Law (Oxford: Oxford University Press, 1997), 139.
} 
enter or encroach on or misappropriate property. This might be understood to imply that the claim for restitution of the transfer is not a remedial right arising to vindicate the primary right of ownership, and this may be why it is widely thought that the claim for restitution does not arise to vindicate any pre-existing right at all, and that instead the claim is itself a primary right. It seems that this is how the claim is understood by commentators who regard it as an unjust enrichment claim rather than a property-based claim. ${ }^{54}$ This position makes no sense to me: a claim arises to correct an injustice, and the injustice must be defined relative to an antecedent primary relation.

It is true that generally there is a duty of exclusion with respect to another person's property, but, although this is a crucial part of a sound regime for the protection of property, it is not the correlate of the right of ownership, and it should not be understood as definitional of the right of ownership. The right of ownership is, more fundamentally, a right to all the benefit of the property: it represents an allocation to the owner of the benefit of the object of property, including prospective or contingent benefit, so that anyone who receives the property incurs a liability to return it or its value, simply by virtue of the receipt, and not by virtue of any wrong. Thus it is an example of the alternative pattern of liability identified above. On this approach, the claim for restitution of an invalid transfer can indeed be understood as vindicating the primary right of ownership. ${ }^{55}$ This approach has the advantage that it obviates the need to rely on the elusive principle of unjust enrichment.

There are other reasons for preferring this as the more basic account of the right of ownership. First, the content of the duty of exclusion should or could reasonably depend on

\footnotetext{
${ }^{54}$ See S Smith, supra note 18.

${ }^{55}$ It is sometimes said that a claim should be characterised by reference to the "causative event" that triggers it, and the causative event cannot be a matter of property law because "property is not an event": the event that generates the claim is the invalid transfer, which is, or causes, an unjust enrichment. As it is also put, "property is a kind of right, while unjust enrichment is a source of rights": Chambers, supra note 10, 264, following Birks. But the issue is how to characterise the causative event. A causative event generates a claim by virtue of a primary relation - the legal relation subsisting before the claim arises, and by virtue of which the event has its legal effect - and it is by reference to this relation - the right of ownership - that it should be characterised.
} 
matters that are not relevant to the right of ownership: for example, it could take the form of a duty to take care not to enter or encroach on the property, but the right of ownership itself surely cannot be qualified in this way. ${ }^{56}$ This reflects the point made above, that the claim for restitution of an invalid transfer should be distinguished from the claim for compensation arising from the breach of a duty not to dispose of property invalidly transferred. Secondly, if the claim arises from a wrong by $\mathrm{D}$, it should in principle always be a personal and not a proprietary claim, because there is no reason why C's remedial right arising from D's wrong should bind third parties who did not commit this, or any other, wrong. Thirdly, the idea of a duty of exclusion does not capture what is distinctive of property cases. For example, is the duty not to assault a person or the duty not to invade his privacy an example of this propertybased duty of exclusion, corresponding to a right of self-ownership and a right of ownership of private information? In my view, these are not property cases, and this is not because some feature of the duty of exclusion in these cases distinguishes them, but because the more fundamental right to the benefit of an object of property is absent in these cases.

\section{The principle of liability behind private property claims}

The second general theoretical concern is that the suggested approach mischaracterises property in a more fundamental way. The approach suggested above implies that there is a doctrinal category of private property, comparable to contract or negligence, consisting of property-based claims based on a common principle of liability. But is there any such principle of liability? One might think that property law is too complex to be understood in this way. In my view, there is such a principle and it should be understood along the following lines.

\footnotetext{
${ }^{56}$ Also, it would be possible in principle to have a case where other parties are free to enter the property but in doing so incur a liability to pay for the unauthorised use.
} 
The significance of private property is that one can invest labour and resources in an object of property, acquiring it, creating it, improving it, maintaining it, or holding it, with a view to receiving the resulting benefit. The principle that the law of private property gives effect to is that someone who has made such an investment of labour or resources in an object of property should receive the resulting benefit ahead of others. The principle protects the interest of someone who has acted on the assumption that he will receive this benefit. Any thing that persists in a well-defined form through time, so that one can link the benefit to be obtained from it with the investment of labour or resources in it, is capable of being an object of property. The law gives effect to the principle, in particular by specifying the things that are recognised in law as objects of property. Of course, the principle cannot itself determine what should be an object of property, that is to say what sorts of thing should be capable of being privately owned; other considerations will be relevant. But this is the basic principle that supports property-based claims, when they arise. ${ }^{57}$ It shows the sense in which the property-based claims considered above are analogous.

A property-based claim secures the benefit of an object of property to its owner. The standard case of a property-based claim is the claim for restitution of an invalid transfer, including a claim to recover a mistaken payment. Another example is the claim for payment for the unauthorised use of property, as where D uses C's land or goods or intellectual property without a licence and is liable to pay a deemed licence fee, the sum that might reasonably have been agreed as a licence fee. The unauthorised use is not a transfer to D, and the claim is not for the recovery of a transfer. The licence fee represents that part of the profits made by $\mathrm{D}$ through the unauthorised use that is attributable to the ownership of the

\footnotetext{
${ }^{57}$ Of course, this brief statement skates over a number of concerns about the principle, but it seems clear that to the extent that a category of private property is justified there is a principle along these lines behind it. The law can also specify the types of benefit and the procedure for acquisition.
} 
property, rather than to the work done by $\mathrm{D}$ in generating the profit. ${ }^{58}$ In my view, it is these claims that arise to vindicate the primary right of ownership, and are distinctive of property, not the claim for compensation arising from the breach of a duty not to cause damage to the property or encroach on it or interfere with its use.

This approach differentiates objects of property from other sorts of interest or benefit that attract legal protection in other ways. For example, it seems to me that a trade secret should be understood as an object of property because the rationale for protection is to give the owner the benefit of his work in creating it, whereas private information should not be understood as an object of property because the rationale for a right in respect of private information is only to avoid harm through its misuse and not to secure to the right-holder the benefit to be gained from the use of the information. ${ }^{59}$ In consequence, in the case of a trade secret, but not private information, there should be a claim for payment for unauthorised use of the information as an object of property, and it should be possible to transfer or licence its use as an object of property. Similarly, the law of defamation does not protect reputation as an object of property, unlike celebrity or personality rights, which (if and when they are recognised in the law) are designed to secure to the claimant the commercial value of his reputation and therefore allow for the licensing of name and image as an object of property. Money and investments in the form of transferable contractual rights to payment are also objects of property. The contractual right, which binds only other contracting parties, can itself be an object of property, and a right of ownership over it can bind other parties, and this is the basis for the recovery of the contractual right or its value if it is invalidly transferred to a third party. In these cases, it is not the presence of a duty not to cause harm or not to interfere or encroach that identifies the right of ownership but the right to the benefit of an object of property.

\footnotetext{
${ }^{58}$ Usually described as a claim for restitutionary damages or licence fee damages. See further Peter Jaffey, "Licence Fee Damages" [2011] Restitution Law Review 95.

${ }^{59}$ Thus the recent division in the old law of confidentiality, supra note 7, is justified.
} 
Labour, or the interest in having control over one's labour, is not an object of property, and the provision of services is not a transfer of an object of property. A claim for payment for the provision of services is not a claim for the return of property or wealth transferred. The theory of unjust enrichment typically treats the provision of services as equivalent to a transfer of property, which amounts to treating labour as an object of property. As mentioned above, the principle of unjust enrichment is often expressed as the principle that unjust enrichments should be reversed. ${ }^{60}$ This seems similar to saying that invalid transfers of property should be reversed, which is an expression of the requirement of vindication as discussed above, the requirement that where there has been an invalid transfer the primary right of ownership over the property should be vindicated by way of a claim to recover the property. The principle that an unjust enrichment should be reversed appears to extend this to the provision of services as well. The appeal of the principle arises from its being presented and understood as if all unjust enrichments were equivalent to invalid transfers of property, but with respect to the provision of services there is no transfer to be reversed because there is no object of property to be recovered. The issue is whether there should be a right to payment in exchange for the benefit conferred, which is a different matter entirely. It is a persistent error in the unjust enrichment literature to equate these different types of case.

The private property principle of liability as stated above is familiar in various guises, and has been put forward as a version of the principle of unjust enrichment, particularly in connection with the unauthorised use of intangible things. For example, say $\mathrm{C}$ has produced a valuable new idea in his business, or has compiled useful commercial information, or has developed a reputation that can be exploited commercially by licensing, and $\mathrm{D}$ uses the idea

\footnotetext{
${ }^{60}$ Supra note 18.
} 
or information or reputation for his own commercial advantage without permission. ${ }^{61}$ The gist of C's complaint is not that $\mathrm{D}$ has caused a loss to $\mathrm{C},{ }^{62}$ but that he has made a profit through the use of a valuable thing that $\mathrm{C}$ created, diverting to himself benefit that $\mathrm{C}$ should be entitled to as the person whose work created the benefit or the opportunity for benefit. This type of claim has long been controversial. It is sometimes expressed as a claim for misappropriation or unfair competition, but also as a claim in unjust enrichment, on the basis that $\mathrm{D}$ is unjustly enriched at C's expense if $\mathrm{C}$ is denied a claim. ${ }^{63}$ Where such a claim is allowed, however, it depends on accepting that the valuable intangible in question is recognised in law as an object of property, and that D has used it without authorisation. The issues concern property and its vindication and, once these issues have been resolved, there is no other substantive question left to address and no room for a principle of unjust enrichment to operate. This type of case involves a claim arising from the unauthorised use of property, but the point is equally true with respect to invalid transfers, as discussed above. In general, the concept of unjust enrichment has nothing to offer to the treatment of property-based claims.

\section{CONCLUSIONS}

The recognition of a new doctrinal category of unjust enrichment is not simply a matter of presentation or labelling. It affects the development of the law through the role of doctrinal categories in legal reasoning. A doctrinal category is sound if it is based on a genuine principle of liability, and it is very difficult to accept that there is a general principle of unjust enrichment to support such a category. The appeal of a category of unjust enrichment lies

\footnotetext{
${ }^{61}$ e.g., International News Services v Associated Press 248 US 215 (1918); cf. Cadbury-Schweppes Pty Ltd v Pub Squash Co. Pty Ltd [1981] 1 WLR 193; Victoria Park Racing and Recreation Grounds Co v Taylor (1937) 58 CLR 479.

62 There may be a separate claim in tort on this basis.

${ }^{63}$ See, e.g., Friedmann, supra note 33, especially at 196-204. See also J Gordley, Foundations of Private Law (Oxford: Oxford University Press, 2006) 423-6.
} 
more in the fact that, in areas like contract and property, it seems impossible, in the light of the conventional understanding of these areas, to account for claims for a restitutionary remedy as claims arising as a matter of contract law or property law, that is to say, as claims arising to vindicate primary rights in contract or property. But the claims for a restitutionary remedy that arise out of a contract or from transfers of property can be explained in terms of contract and property, without the need for the supposed principle of unjust enrichment. This emerges from an exploration of the nature of the principles of liability that support these categories.

There are persistent problems in the areas of law discussed above - for example, when should a contracting party be entitled to recover a prepayment, what should the tracing rules be, or when should a claim to recover a mistaken payment or some other invalid transfer be proprietary - for which one might expect the theory of unjust enrichment to offer solutions. But if my approach is right, although the category of unjust enrichment is becoming well established, it is destined not to solve these or any other problems, or more generally to promote the development of the law for the better, but instead, like its predecessor the theory of quasi-contract, to obscure the real issues at stake and obstruct the sound development of the law. 